УДК821.161.2-311.1.09

Бортневська Н. В., аспірант кафедри української літератури

КДПУ імені В. Винниченка

(м. Кропивницький)

\title{
ПОЕТИКА ПСИХОЛОГІЗМУ ЧОЛОВІЧИХ ОБРАЗІВ (НА МАТЕРІАЛІ ОПОВІДАННЯ ВОЛОДИМИРА ВИННИЧЕНКА «КРАСА І СИЛА»)
}

У статті розглядаються художні засоби зображення внутрішнього світу героївчоловіків в оповіднні Володимира Винниченка «Краса $і$ сила». Покладаючись на теорію архетипів К. Г. Юнга, здійснено спробу простежити оприявлення Самості й Тіні героїв, щэо виходять назовні у конфліктних ситуачіях певних епізодів твору.

Ключові слова: маскулінність, психологізм, архетип, афект, Самість, Тінь.

В статье рассматриваются способы изображения внутреннего мира героев-мужчин в рссказе Владимира Винниченко «Красота и сила». Полагаясь на теорию архетипов К. Г. Юнга, предпринята попытка проследить олищетворении Самости и Тени героев, которые выходят наружу в конфликтных ситуачиях определенных эпизодов произведения.

Ключевые слова: маскулинность, психологизм, архети, аффект, Самость, Тень.

The article represents artistic devices that reveal inner world of the male characters in the novel "Beauty and strength» by Volodymyr Vynnychenko. Based on the Carl Jung's theory of archetypes, the author made an attempt to trace the personation of the characters' selfhood and shadow that appear in conflict situations in the novel.

Keywords: masculinity, psychologism, archetype, affect, selfhood, shadow.

Навколо постаті Володимира Винниченка друге століття поспіль не вщухають наукові дискусії щодо його життєвого шляху і творчого доробку. Це неминуче, адже митець став однією із ключових персоналій початку $\mathrm{XX}$ століття як у літературному, так і в суспільному житті нашого народу. Актуалізований письменник і в сучасному літературознавчому дискурсі осмислюється його драматургія, проза, філософські тексти автора. Нині прийшов час глибокого осягнення поетики його творів, які, безсумнівно, $\epsilon$ важливими у розвитку української літератури доби модернізму. 
Одним із нерозв’язаних досі завдань залишається дослідження маскулінного дискурсу творчості Володимира Винниченка, оскільки відчувається зміщення акцентів на розробку фемінного: значну увагу в інтерпретації творів автора було присвячено жіночим персонажам, зокрема у наукових працях Л. Мороз, Г. Костюка, В. Панченка, С. Михиди, М. Ковалик та ін. Однак, завдяки високому рівню психологічної достовірності, серйозне значення в розкритті авторського задуму і високої художності творів митця в цілому мають і герої-чоловіки. Інтерес до психологізму при вивченні літератури доби модернізму в сучасному літературознавстві цілком закономірний, адже $є$ однією 3 визначальних рис поетики літературного напряму в цілому i Володимира Винниченка зокрема, що актуалізує нашу розвідку, мета якої - сформувати уявлення про оригінальні авторські художні прийоми психологізації чоловічих персонажів. Об'єктом статті при цьому постає повість «Краса і сила» Володимира Винниченка.

Специфіці художнього психологізму малої прози Володимира Винниченка було присвячено дисертаційні проекти Л. Мацевко та С. Присяжнюк [Мацевко 2000; Присяжнюк 2006]. Ми ж пропонуємо зосередити увагу на засобах, за допомогою яких розкривається внутрішній світ героївчоловіків, покладаючись на теорію архетипів К. Г. Юнга [Юнг 1996].

Вибір тексту для подібної розвідки не випадковий. Насамперед, «Краса i сила» - це дебютне оповідання Володимира Винниченка, в рецензії на яке I. Франко зауважував причину «тріумфу»: «Се оповідання, $з$ яким Винниченко виступив на поле украӥнського письменства, було й периим його тріумфом; воно збудоване дуже гарно, визначається незвичайною драматичністю та ярким колоритом, а при тім певною, пластичною $і$ вірною характеристикою дієвих осіб» [Франко 1907:140]. А Г. Костюк, підкреслюючи модернізацію створених образів у творі «Краса і сила», писав: «саме ие оповідання зіграє в новітній історії украӥнської літератури роль межового каменя, межового стовпа між двома літературними епохами» [Костюк 1999:15]. 
Основу сюжету твору складають стосунки поміж містечковими злодіями Ільком Чубатим та Андрієм Голубом та жінкою - Мотрею Чумарченко донькою удівця-п’яниці, в центрі ж конфлікту оповідання, на думку В. Панченка, постають внутрішні хитання головної героїні, «боротьба мотивів», однак, дослідник наголошує, що «чоловічі персонажі відіграють не останню роль у тлумаченні загадки внутрішній колізій Мотрі» [Панченко 1998:44].

Образ жінки в оповіданні «Краса і сила» можна розглядати скоріше як інструмент, завдяки якому розкривається внутрішній світ героїв-чоловіків. Для деталізації нашої позиції залучаємо класифікацію архетипів К. Г. Юнга. Володимир Винниченко, на нашу думку, створює образ Мотрі - індикатора Тіні чоловічої душі у творі, що розкриває їхні слабкості, комплекси, витіснені 3 бажання тощо. I саме через призму споглядання і оціночних характеристик Мотрі щодо чоловічих персонажів, перед читачем постають портрети i характери Андрія та Ілька. Водночас образ Мотрі вибудовується через споглядання іï чоловічими персонажами.

За спостереженням Л. Золотюк: «Із кожним чоловіком Мотря поводить себе по-різному. 3 пасивним Ільком виявляє енергію $i$ завзятість <... . У стосунках із Андрієм вона грає роль покірної жінки, а значить - пасивної, а сам Андрій - роль агресора (активне начало). Якщуо пасивність Ілька співвідноситься із фемінністю, то агресія, садизм $і$ суперництво Андрія внутрішньо властиві маскулінності» [Золотюк 2010:17].

О. Костенко зазначає, що специфічною ознакою мистецького почерку Володимира Винниченка $є$ діалектичний стиль викладу, що виражається у тенденції до зображення драматичних, конфліктних ситуацій, при цьому: «провідним мотиваційним чинником, щзо визначає характер міжособистісних конфронтацій, детермінує розгортання сюжету, постає бажання першості або прагнення до психологічної і(чи), як наслідок, фізичної переваги над супротивником» [Костенко 2010:7]. Такий тип взаємин показовий у творі на 
прикладі стосунків Ілька - Андрія. Засобом викриття суті внутрішнього світу цих чоловіків і є жіночий персонаж твору.

Хитання Мотрі, яка ніби не може обрати між «сильним» і «красивим», відображують внутрішні вагання героїв, їхню непостійність, невизначеність. Автор не показує відкритого протистояння поміж злодіями-парубками, які «ділять» одну жінку, навпаки, вони друзі, навіть не сваряться, а от поява Мотрі провокує внутрішній вияв героїв зовсім в іншій іпостасі. У Андрія викликає агресію, дає змогу розкрити, «вилити» його підсвідоме у дію: «Як дикий звір накинувся він на неї $і$ почав топтать ї̈ ногами, бить передками черевиків $у$ боки, в спину, в живіт, шарпаючи за коси, з піною на губах, з якимсь хриплим ревом...» [Винниченко 1989:28]. Андрієві жінка потрібна для самоствердження, адже, принижуючи ії, він самореалізується як чоловік. Присутність Мотрі поряд з Ільком доводить його до стану афекту. О. Сурова цілком справедливо трактує таку ситуацію в контексті аналітичної психології К. Г. Юнга, котрий розглядав реакцію, обтяжену афектом, як ключ до вияву комплексу, тобто «психічного фрагменту», що «відколовся» від психіки людини в результаті травмуючих впливів (цей комплекс перешкоджає здійсненню передбачених, вольових дій та порушує діяльність свідомості). Тобто, «афект, щзо спалахує всупереч волі людини, показує «величину» рани, нанесеної ї̈ психіці» [Сурова:57].

Конфлікт Мотрі з Андрієм розгортається у присутності Ілька, байдужість якого розкривається через так званий «кодекс честі» грабіжників та розбійників [Михида 2002:23]. Забувши про свою обіцянку заступитись, він говорить: " - Та про мене! - здвигнув Ілько плечима, нахиляючи голову набік $i$ махнувии рукою. - Вб’єи, сам одвічать будеш» [Винниченко 1989:29].

Ілько не бажає конфронтації з Андрієм через жінку. Поза стосунками 3 Мотрею, Ілько - злодій «...якого сам батько одчурався, а добрі люди десятою вулицею обминають, з яким мають діло тільки його приятелі, такі ж як $і$ він, злодіï» [Винниченко 1989:21]. За силою Ілько рівний суперник Андрію. Його товариш сам визнає, що фізичною силою він (Ілько) не обділений: «... як тому 
ковбасникові щеелепи звернув?», «A то ти $i$ змалечку усе б'єшся» [Винниченко 1989:31].

Проте перед Мотрею Ілько не виявляє своєї сили, не показує себе чоловіком-захисником, що й підтверджує той факт, що «любовний трикутник»- умовний. Для злодія головне відповідати кодексу у своєму середовищі, жінка не потрібна йому для створення сім'ї, кохання. Її образ у цьому випадку $є$ твірним елементом композиції, що допомагає розкрити психотипи героїв-чоловіків яскраво, адже поза стосунками 3 протилежною статтю вони не відкривають свого прихованого внутрішнього світу і не конфліктують.

У дослідженні М. Ковалик йдеться про те, «щ̧о Мотря $\epsilon$ героїнею традииійного для української літератури мелодраматичного конфлікту любовного трикутника, але модернізованого завдяки новаторському протиставленню краси (Ілько) i сили (Андрій)» [Ковалик 2013:276]. Однак, відповідно до завдання нашої розвідки, ми припускаємо, що трикутник, створений автором у повісті не для того, щоб увиразнити драму героїв, а для того, аби продемонструвати внутрішній світ чоловічих образів, що розкривається у ході подій. При цьому присутність жіночого персонажу допомагає оприявити підсвідоме чоловіків назовні.

Вирішальним епізодом у творі постає конфлікт, що виникає через провокацію Андрія, котрий мучить голуба і змушує Ілька до конфронтації: " - Та не бий!! - крикнула Мотря. Андрій навіть не підняв голови і став злорадно бить по ногах, по крилах, по голові переляканого жовто-рябого. - Та пусти, не муч! - крикнув Ілько. Наміряючись уже пустить, Андрій по сих словах мовчки злісно глянув на Ілька, усміхнувся й, схопивши ніжку жовторябого, крутнув. Почувся легенький хруск, голуб несамовито забився й затріпався, - Андрій зламав йому ніжку. Сей хруск, розкритий вмить рот жовто-рябого, безсиле його тріпання - все наче морозом пройняло Ількові miлo» [Винниченко 1989:65] (підкреслення наше. - Н. Б.). Спричиняється кривава бійка між героями-чоловіками, але не за «кохану» жінку, а за птаха. 
О. Костенко щодо такого конфлікту слушно зазначає, що «поруч із зовнішніми подразниками (середовищее, оточення) та внутрішніми стимулами, щ⿻о посилюють бажання, визначальну роль відіграє ситуативний фактор. Свого апогею чуттєве досягає під впливом провокуючої подї, яка веде до розв 'язання конфлікту» [Костенко 2010:9].

За спостереженням Л. Золотюк: «Голуб - ц̧е образ Андрієвої душі, надломленої його ж силою: прагнення усунути у любовних стосунках суперника - Ілька - породжує в ньому агресивні імпульси, які призвичаюють героя розв'язувати конфлікти через садизм, у результаті - втрачається та символічна святість голуба-душі» [Золотюк 2010:16]. На нашу думку, голуб символ, що уособлює Самість Ілька, яка не позбавлена людяності. Як наслідок - Ілько заступається і вступає в бійку з Андрієм: «Пусти, не муч!.. глухо прохрипів червоний, 3 піною на губах, важко дихаючи, Ілько» [Винниченко 1989:65], а характеристика Мотрею того ж Ілька допомагає увиразнити його Самість: « - Та чого ти присікався до його? - сухо промовила Мотря. - Випустить!. Який сердобольний!» [Винниченко 1989:65]. Водночас символічний образ голуба відкриває Тінь у Андрія: « - A тобі яке діло?! блідий, аж жовтий, з синіми губами глянув на його ненависно Андрій, не випускаючи голуба»... «Андрій важко дихав, з презирством усміхався $і$ мовчки копався в кишені, не випускаючи голуба» [Винниченко 1989:65] (підкреслення наше. - Н. Б.).

Подібний випадок демонстрації підсвідомого у героя зустрічається в романі Панаса Мирного «Хіба ревуть воли, як ясла повні?», де зображено вчинок головного персонажа - Чіпки, що пропонує своєму товаришеві скручувати голови горобцям:

" - Стривай, Грищьку! стривай! не бий... Давай кращуе їм голови поскручуємо!..

Як схопить горобеня, як крутне за головку... Не вспів оком моргнути, - в одній руиі зостався тулубецьь, а в другій - головка. <..> 
Незабаром горобенят не стало: валялися тільки одні головки та тулубиі...» [Мирний 1963:36-37].

Як бачимо, вчинок Чіпки у реалістичному творі Панаса Мирного та Андрія у творі доби модернізму Володимира Винниченка - суголосні, так як i типи чоловічих образів, зображених у них. У епізоді на пасовиську, де ніби зовсім випадково малому хлопцеві раптом захотілось поскручувати голови пташенятам, Панас Мирний зобразив Тінь Чіпки, яка виходить назовні i виявляється у формі садизму. I теж певною мірою доводить героя до стану афекту: «Очі горять, сам труситься...» [Мирний 1963:119] (підкреслення наше. - Н. Б.).

Загальновідомо, що християнство послуговується образом голуба як символом душі. Вважається, ніби душа з людини виходить у образі голуба. Саме голуб персоніфікує собою Святого Духа, перехід від одного стану до іншого. Образ птахів у творах - символічний, в одному випадку - образ горобців, в іншому - образ голуба-душі, що певною мірою пов’язані з Христом. Однак, П. Мирний використовує символ проклятих Христом птахів - горобців (ніби виправдовуючи Чіпку), а В. Винниченко, символ голуба навантажує потроєною значущістю, вкладаючи в його святість, колір (бо Андрій був рудим) i навіть прізвище у Андрія - Голуб. Таким чином, автор, привертає увагу читача до створеного образу-символу, що містить у собі глибоке смислове навантаження і стає вирішальним у розв'язанні внутрішнього конфлікту твору. Разом $з$ тим, образ «хруску» - іє тією «межовою ситуащчією», що розкриває внутрішній світ героїв і допомагає експлікувати Тінь у Андрія та Чіпки, а Самість у Ілька.

У оповіданні «Краса і сила» Володимир Винниченко створює чоловічих персонажів, які втілюють різні смисли. Автор підняв пласти дійсності і показав як діють герої у різному середовищі. Він розкриває закономірності чоловічих образів, долаючи стереотипи неспроможності i вибудовуючи новий тип чоловіка, котрий здатен на вчинок, однак обставини визначають його роль. Самість, яка прагне до самовиявлення в Ілька, вступає в конфлікт 3 
обставинами. Андрій же - це втілення матеріального світу, його вчинки $\epsilon$ інтенцією виходу 3 Тіні, в нашому спостереженні, а у випадку 3 Ільком пробудження Самості, яка прагне до самовияву.

Підсумовуючи, слід зазначити, що об’єктом уваги при розкритті підсвідомого чоловічих персонажів стали образи Мотрі та голуба. На нашу думку, Володимир Винниченко, для увиразнення психологічних особливостей героїв-чоловіків оповідання «Краса і сила», і ставить їх поряд 3 жінкою, бо вона провокує їх на розкриття прихованого внутрішнього світу, оскільки усе те, що відбувається назовні - типово для певного середовища людей. А образ голуба $є$ символом оприявлення підсвідомого персонажів-чоловіків і постає завершальним у вирішенні внутрішнього конфлікту героїв повісті.

Отож, розглянувши художні прийоми психологізації чоловічих образів можемо говорити про те, що Володимир Винниченко веде внутрішню дискусію персонажів у парадоксі, письменник створює умовний «любовний трикутник», який стає засобом розкриття внутрішнього світу героїв. Простежується Самість у Ілька, який на фоні міжособистісних стосунків 3 жінкою нерішучий в своїх діях, не бажає відстояти своєї позиції (хоча й має для цього всі можливості), але це йому не потрібно, бо нема кохання як такого, нема мети - створити сім'ю, наприклад, однак простежується рішучість у більш глибокому - вчинку людяному, по відношенню до птаха, що уособлює собою святе - душу. А от у Андрія простежуються патріархальні ознаки, він навіть одружиться з Мотрею, але не для сімейного затишку, а для самоствердження, самореалізації. Тому жіночий персонаж, як і символічний образ голуба у творі - це індикатори Тіні, яка оприявлює суть чоловічих образів і $\epsilon$ засобом розкриття їх внутрішнього Его.

У оповіданні «Краса і сила» Володимир Винниченко створює два типи чоловіків, які уособлюють собою типи - образ «сили», образ «краси», які трансформуватимуться i в наступних творах автора, створюючи парадигму психотипів чоловічих образів в усьому доробку письменника i стануть об'єктами наших подальших спостережень та розвідок. 


\section{БІБЛІОГРАФІЯ}

Винниченко 1989 - Винниченко Володимир. Краса і сила / Володимир Винниченко; [упор., авт. прим. Павло Федченко, авт. передм. Ігор Дзеверін]. К. : Дніпро, 1989. - 752 с.

Володимир Винниченко: viribus unitis - XXI. Частина перша (життя i творчість В. Винниченка в наукових дослідженнях С. Михиди та М. Ковалик). Кіровоград: «Поліграф-Сервіс», 2013. - 432 с. - (серія «Стилет і стилос трьох степовиків»).

Золотюк 2010 - Золотюк Л. Особливості портретописання i характеротворення у повісті «Краса і сила» Володимира Винниченка / Л. Золотюк // Літеруторознавчі обрії. Праці молодих учених. Випуск 18. - К. : Інститут літератури ім. Т. Г. Шевченка НАН України, 2010 - С. 12-18.

Костенко 2010 - Костенко О. Мала проза Володимира Винниченка: особливості психологічного мотивування / О. Костенко // Літературознавчі обрії. Праці молодих учених. - Вип. 18. - К. : Інститут літератури ім. Т. Г. Шевченка НАН України, 2010 - С. 5-11.

Костюк 1999 - Костюк Г. Світ Винниченкових образів та ідей / Г. Костюк // Слово і час. - 1999. - №7. - С. 14-26.

Мацевко 2000 - Мацевко Л. В. Винниченко та І. Бунін : Еволюція психологізму в малій прозі: дис... канд. філол. наук: 10.01 .06 / Мацевко Лідія Василівна. - Львів, 2000. - 207 с.

Мирний 1963 - Мирний П. Хіба ревуть воли, як ясла повні? : роман / П. Мирний, І. Білик. - К. : Худ. літ., 1963. - 349 с.

Михида 2002 - Михида Сергій. Слідами його експериментів: Змістові домінанти та поетика конфлікту в драматургії Володимира Винниченка / Сергій Михида. - Кіровоград: Центрально-Українське видавництво, 2002. - 192 с.

Панченко 1998 - Панченко В. С. Будинок 3 химерами. Творчість В. Винниченка 1900-1920 pp. у європейському літературному контексті : Монографія / Володимир Євгенович Панченко. - Кіровоград, 1998. - 272 с. 
Присяжнюк 2006 - Присяжнюк С. С. Психологізм дитячих оповідань Володимира Винниченка (принципи, засоби зображення характерів) : автореф. дис. на здобуття наук. ступеня канд. філол. наук: 10.01.01. «Українська література» / С. С. Присяжнюк. - Кіровоград, 2006. - 24 с.

Сурова О. Человек в модернистской культуре. [Електронний ресурс] / О. Сурова. - Режим доступу: www. Philol.msu.ru /forlit/ Pages / Biblioteka Surova. htm.

Франко 1907 - Франко I. Новини нашої літератури // Літературнонауковий вісник. - К., 1907. - Т. 38, кн. 10. - С. 139-141.

Юнг 1996 - Юнг К. Г. Психологические типы / К. Г. Юнг. - М. : Университетская книга, АСТ, 1996. - 714 с. 